\title{
Letter of Credit (L/C) dalam Produk Bank Syariah
}

Khoiruddin

Institut Agama Islam Negeri (IAIN) Raden Intan Bandar Lampung alfan_abiya@yahoo.co.id

\begin{abstract}
:
The existence of letter of credit which is really accordance with Islamic syariah principles has been waited by moslem bussinessmen who want to run their religion values in all their life. The conventional $\mathrm{L} / \mathrm{C}$ is considered as on syariah $\mathrm{L} / \mathrm{C}$ due to its practice still applicates the interest system. The regulation of L/C Syariah has been existed in Act No. 21/2008 concerning Perbankan Syariah, in article $19 \mathrm{p}$, and long before the act was made, the existence of L/C Syariah has been mentioned in Fatwa Dewan Syariah Nasional MUI NO.34/DSN-MUI/IX/2002 concerning L/C Impor Syariah and Fatwa Dewan Syariah Nasional MUI No. 35/DSN-MUI/IX/2002 concerning L/C Ekspor Syariah. L/C Syariah can applicate some models of akads/ contracts, such as: wakālah bi al-ujrah, qarḍ, murābaḥah, salām/istiṣnā', muḍarabah, mushārakah, hawālah and al-bai'. From the variety of contract models which can be applicated to the L/C Syariah, wakālah bi al-ujrah and muräbahah are considered as the most efficient, safest, and the most minimum risky. Wakālah bi al-ujrah and murābaḥah are also an agreement that closest to the goal of $\mathrm{L} / \mathrm{C}$ existence, that is: makes the international trade process become easier.
\end{abstract}

Keywords: L/C Syariah, wakālah bi al-ujrah, murābaḥah.

\section{Pendahuluan}

Transaksi perdagangan dewasa ini mengalami perkembangan yang sangat pesat. Wajar jika dalam proses perkembangannya, muncul banyak problem dan sekaligus cara mengatasinya. Di antara problem tersebut adalah probem jarak antara eksportir dan importir. Untuk membagi dan mengurangi risiko masing-masing pihak yang disebabkan oleh jarak dan faktor tidak saling mengenal antara eksportir dan importir, maka lazim dikenal cara pembayaran dengan Letter of Credit (L/C). Pembayaran melalui L/C 
merupakan alat pembayaran transaksi perdagangan antarnegara, yang paling sering digunakan.

L/C menjadi alat pembayaran primadona dalam transaksi bisnis antarnegara karena merupakan alat pembayaran yang paling aman di mana risiko bagi eksportir dan importir dapat dialihkan pada pihak bank. Hal ini dapat dilihat dari pengertian L/C sebagai "jaminan pembayaran bersyarat" yang merupakan surat yang diterbitkan oleh bank (issuing bank) atas permintaan importir yang ditujukan kepada bank lain di negara eksportir (advising/negotiating bank) untuk kepentingan pihak eksportir (beneficiary/ penikmat) di mana eksportir diberi hak untuk menarik wesel-wesel atas importir yang bersangkutan sebesar jumlah uang yang disebutkan dalam surat itu (Widjaja, 2001: 24).

Akan tetapi mekanisme transaksi L/C impor maupun L/C ekspor konvensional yang merupakan salah satu jasa perbankan dinilai tidak sesuai dengan prinsip-prinsip syariah. Penentuan biaya pelaksanaan L/C yang kurang transparan dan adanya unsur bunga demi keuntungan bank terkait pemberian fasilitas pinjaman bagi importir yang tidak mempunyai dana yang cukup di bank, merupakan suatu hal yang bertentangan dengan prinsip syariah. Maka untuk mengatasi masalah tersebut, dan dalam rangka memenuhi kebutuhan masyarakat untuk penerapan prinsip syariah dalam kegiatan bisnis, termasuk dalam perdagangan internasional, kemudian muncullah L/ C dalam perbankan syariah yang berbasis syariah, yaitu L/C impor dan ekspor syariah.

Berdasarkan fatwa Dewan Syariah Nasional tentang L/C Impor Syariah, pelaksanaan L/C impor syariah dapat menggunakan akad-akad wakālah bi al-ujrah, qarḍ, murābaḥah, salām/istiṣnā', muḍārabah, mushārakah, dan hawāălah. Untuk L/C ekspor syariah dalam pelaksanaannya dapat menggunakan akad-akad wakālah bi al-ujrah, qarḍ, muḍārabah, mushārakah dan al-bai' (Fatwa DSN, 2003: 211-232).

Tetapi muncul suatu pertanyaan, apakah akad-akad tersebut telah sesuai dengan esensi dari Letter of Credit (L/C) yang sesungguhnya. Mengingat $\mathrm{L} / \mathrm{C}$ merupakan produk jasa bank, di mana bank hanya akan mendapatkan fee dari jasa yang diberikan. Tetapi dalam proses penyelesaian, produk ini juga bisa beralih menjadi kredit biasa, di mana bank tidak 
mendapatkan fee tetapi bank akan mendapatkan profit margin dari transaksi yang dilakukan.

\section{Pengertian dan Bentuk Akad L/C Syariah}

Letter of Credit (L/C) dalam bahasa Indonesia disebut sebagai Surat Kredit Berdokumen. L/C merupakan salah satu jasa yang ditawarkan oleh bank dalam rangka pembelian suatu barang, berupa penangguhan pembayaran pembelian oleh pembeli (importir) sejak L/C dibuka sampai dengan jangka waktu tertentu sesuai perjanjian (Budisantoso, 2006: 128).

Kasmir menilai Letter of Credit (L/C) adalah jasa bank yang diberikan kepada masyarakat untuk memperlancar arus barang (ekspor-impor) termasuk dalam negeri (antarpulau). Di mana L/C berguna untuk menampung dan menyelesaikan kesulitan-kesulitan yang diemban pembeli (importir) maupun penjual (eksportir) dalam transaksi jual beli yang dilakukannya. Lebih lanjut Kasmir mendefinisikan L/C adalah suatu pernyataan dari bank atas permintaan nasabah (importir) untuk menyediakan dan membayar sejumlah uang tertentu untuk kepentingan pihak ketiga (penerima L/C atau eksportir) (Kasmir, 2002: 152).

Secara umum L/C dalam pengertian bank konvensional digunakan untuk membiayai sales contract jarak jauh antara pembeli dan penjual yang belum saling mengenal dengan baik. Lebih jelasnya L/C digunakan untuk membiayai transaksi Perdagangan Internasional (Ginting, 2002: 15). Menurut ketentuan Uniform Customs and Practice for Documentary Credits (UCPDC 600), L/C merupakan janji dari bank penerbit untuk melakukan pembayaran atau memberi kuasa kepada bank lain untuk melakukan pembayaran kepada penerima atas penyerahan dokumen-dokumen yang sesuai dengan persyaratan L/C. Inti dari pengertian L/C di sini adalah bahwa L/C merupakan janji membayar (Widjaja, 2001: 8). Sedangkan menurut Bank Indonesia, L/ $\mathrm{C}$ merupakan janji dari issuing bank untuk membayar sejumlah uang kepada eksportir sepanjang ia dapat memenuhi syarat dan kondisi L/C tersebut (Bank Indonesia, 2008: C-1).

Letter of Credit (L/C) dalam bank syariah termasuk produk pembiayaan, yaitu pembiayaan Letter of Credit (L/C) impor atau ekspor syariah. Sebagaimana yang dikatakan oleh Adiwarman A. Karim, secara definitif 
yang dimaksud dengan Letter of Credit (L/C) adalah pembiayaan yang diberikan dalam rangka memfasilitasi transaksi impor atau ekspor nasabah (Karim, 2008: 252).

L/C syariah terbagi menjadi dua, L/C impor syariah dan $\mathrm{L} / \mathrm{C}$ ekspor syariah. Dalam Kodifikasi Produk Perbankan Syariah yang dibuat oleh Bank Indonesia (BI), disebutkan bahwa $\mathrm{L} / \mathrm{C}$ impor syariah adalah surat pernyataan akan membayar kepada eksportir (beneficiary) yang diterbitkan oleh bank (issuing bank) atas permintaan importir dengan pemenuhan persyaratan tertentu sesuai dengan prinsip syariah (Fatwa DSN, 2003: 217). Sedangkan L/C ekspor syariah adalah surat pernyataan akan membayar kepada eksportir yang diterbitkan oleh Bank untuk memfasilitasi perdagangan ekspor dengan pemenuhan persyaratan tertentu sesuai dengan prinsip syariah (Fatwa DSN, 2003: 228).

Berdasarkan Fatwa No. 34/DSN-MUI/IX/2002, ketentuan akad-akad untuk Letter of Credit (L/C) Impor yang sesuai dengan syariah dapat digunakan beberapa bentuk:

1. Akad wakālah bi al-ujrah, dengan ketentuan:

a. Importir harus memiliki dana pada bank sebesar harga pembayaran barang yang diimpor;

b. Importir dan bank melakukan akad wakālah bi al-ujrah untuk pengurusan dokumen-dokumen transaksi impor;

c. Besar ujrah harus disepakati di awal dan dinyatakan dalam bentuk nominal, bukan dalam bentuk persentase.

2. Akad wakālah bi al-ujrah dan qard, dengan ketentuan:

a. Importir tidak memiliki dana cukup pada bank untuk pembayaran harga barang yang diimpor;

b. Importir dan bank melakukan akad wakālah bi al-ujrah untuk pengurusan dokumen-dokumen transaksi impor;

c. Besar ujrah harus disepakati di awal dan dinyatakan dalam bentuk nominal, bukan dalam bentuk persentase;

d. Bank memberikan dana talangan (qarḍ) kepada importir untuk pelunasan pembayaran barang impor. 
3. Akad murābahah dengan ketentuan:

a. Bank bertindak selaku pembeli yang mewakilkan kepada importir untuk melakukan transaksi dengan eksportir;

b. Pengurusan dokumen dan pembayaran dilakukan oleh bank saat dokumen diterima (at sight) dan/atau tangguh sampai dengan jatuh tempo (usance);

c. Bank menjual barang secara murābaḥah kepada importir, baik dengan pembayaran tunai maupun cicilan.

d. Biaya-biaya yang dikeluarkan oleh bank akan diperhitungkan sebagai harga perolehan barang.

4. Akad salām/istiṣnā' dan murābaḥah, dengan ketentuan:

a. Bank melakukan akad salām atau istiṣnā' dengan mewakilkan kepada importir untuk melakukan transaksi tersebut.

b. Pengurusan dokumen dan pembayaran dilakukan oleh bank;

c. Bank menjual barang secara murābaḥah kepada importir, baik dengan pembayaran tunai maupun cicilan.

d. Biaya-biaya yang dikeluarkan oleh bank akan diperhitungkan sebagai harga perolehan barang.

5. Akad wakālah bi al-ujrah dan muḍaarabah, dengan ketentuan:

a. Nasabah melakukan akad wakālah bi al-ujrah kepada bank untuk melakukan pengurusan dokumen dan pembayaran.

b. Bank dan importir melakukan akad muḍārabah, di mana bank bertindak selaku șạhibu al-māl menyerahkan modal kepada importir sebesar harga barang yang diimpor.

6. Akad mushārakah, dengan ketentuan:

Bank dan importir melakukan akad mushārakah, di mana keduanya menyertakan modal untuk melakukan kegiatan impor barang.

7. Dalam hal pengiriman barang telah terjadi, sedangkan pembayaran belum dilakukan, akad yang digunakan adalah:

Alternatif I : wakālah bi al-ujrah dan qarḍ, dengan ketentuan:

a. Importir tidak memiliki dana cukup pada bank untuk pembayaran harga barang yang diimpor; 
b. Importir dan bank melakukan akad wakālah bi al-ujrah untuk pengurusan dokumen-dokumen transaksi impor;

c. Besar ujrah harus disepakati di awal dan dinyatakan dalam bentuk nominal, bukan dalam bentuk persentase;

d. Bank memberikan dana talangan (qard) kepada nasabah untuk pelunasan pembayaran barang impor.

Alternatif II: wakālah bi al-ujrah dan ḥawālah, dengan ketentuan:

a. Importir tidak memiliki dana cukup pada bank untuk pembayaran harga barang yang diimpor;

b. Importir dan bank melakukan akad wakālah untuk pengurusan dokumen-dokumen transaksi impor;

c. Besar ujrah harus disepakati di awal dan dinyatakan dalam bentuk nominal, bukan dalam bentuk persentase;

d. Utang kepada eksportir dialihkan oleh importir menjadi utang kepada bank dengan meminta bank membayar kepada eksportir senilai barang yang diimpor (Fatwa DSN, 2003: 218).

Sedangkan dalam Fatwa no.35/DSN-MUI/IX/2002, ketentuan akadakad untuk Letter of Credit (L/C) Ekspor yang sesuai dengan syariah dapat berupa:

1. Akad wakālah bi al-ujrah, dengan ketentuan:

a. Bank melakukan pengurusan dokumen-dokumen ekspor;

b. Bank melakukan penagihan (collection) kepada bank penerbit L/C (issuing bank), selanjutnya dibayarkan kepada eksportir setelah dikurangi ujrah;

c. Besar ujrah harus disepakati di awal dan dinyatakan dalam bentuk nominal, bukan dalam bentuk persentase.

2. Akad wakālah bi al-ujrah dan qard, dengan ketentuan:

a. Bank melakukan pengurusan dokumen-dokumen ekspor;

b. Bank melakukan penagihan (collection) kepada bank penerbit L/C (issuing bank);

c. Bank memberikan dana talangan (qard) kepada nasabah eksportir sebesar harga barang ekspor; 
d. Besar ujrah harus disepakati di awal dan dinyatakan dalam bentuk nominal, bukan dalam bentuk persentase;

e. Pembayaran ujrah dapat diambil dari dana talangan sesuai kesepakatan dalam akad;

f. Antara akad wakālah bi al-ujrah dan akad qard, tidak dibolehkan adanya keterkaitan (ta'alluq).

3. Akad wakālah bi al-ujrah dan muḍārabah, dengan ketentuan:

a. Bank memberikan kepada eksportir seluruh dana yang dibutuhkan dalam proses produksi barang ekspor yang dipesan oleh importir;

b. Bank melakukan pengurusan dokumen-dokumen ekspor;

c. Bank melakukan penagihan (collection) kepada bank L/C (issuing bank);

d. Pembayaran oleh bank penerbit L/C dapat dilakukan pada saat dokumen diterima (at sight) atau pada saat jatuh tempo (usance);

e. Pembayaran dari bank penerbit L/C (issuing bank) dapat digunakan untuk:

- Pembayaran ujrah;

- Pengembalian dana mudārabah;

- Pembayaran bagi hasil

f. Besar ujrah harus disepakati di awal dan dinyatakan dalam bentuk nominal, bukan dalam bentuk persentase.

4. Akad mushārakah, dengan ketentuan:

a. Bank memberikan kepada eksportir sebagian dana yang dibutuhkan dalam proses produksi barang ekspor yang dipesan oleh importir;

b. Bank melakukan pengurusan dokumen-dokumen ekspor;

c. Bank melakukan penagihan (collection) kepada bank penerbit L/C (issuing bank);

d. Pembayaran oleh bank penerbit L/C dapat dilakukan pada saat dokumen diterima (sight) atau pada saat jatuh tempo (usance);

e. Pembayaran dari bank penerbit L/C (issuing bank) dapat digunakan untuk: 
- Pengembalian dana mushārakah;

- Pembayaran bagi hasil.

5. Akad al-Bai' (Jual Beli) dan wakālah, dengan ketentuan:

a. Bank membeli barang dari eksportir;

b. Bank menjual barang kepada importir yang diwakili eksportir;

c. Bank membayar kepada eksportir setelah pengiriman barang kepada importir;

d. Pembayaran oleh bank penerbit L/C (issuing bank) dapat dilakukan pada saat dokumen diterima (at sight) atau pada saat jatuh tempo.

Sistem sewa beli ada dalam perbankan syariah, biasa disebut dengan pembiayaan investasi al-ijärah al-muntahia bi al-tamlike, yaitu menyewakan barang modal dengan opsi diakhiri dengan pemilikan. Sumber perusahaan untuk pembayaran sewa ini adalah amortisasi atas barang modal yang bersangkutan, surplus, dan sumber-sumber lain yang dapat diperoleh perusahaan (Fatwa DSN, 2003: 229-231).

\section{Proses Terbentuknya L/C}

Bank tidak hanya mengandalkan sumber penerimaan utamanya dari penyaluran kredit melainkan juga dari jasa-jasa yang diberikan. Penerimaan (income) yang berasal dari pemberian jasa-jasa ini dalam perbankan disebut sebagai fee-based income. Bentuk jasa-jasa ini selalu mengalami perkembangan dari waktu ke waktu. Salah satu jasa yang ditawarkan oleh bank adalah letter of credit (Pandia, 2005: 194).

Pada bank konvensional L/C dimasukkan sebagai non-cash Loan dan disebut sebagai fee-based income (penerimaan yang berasal dari pemberian jasa nonpembiayaan atau investasi). Begitu juga dalam bank syariah $\mathrm{L} / \mathrm{C}$ dimasukkan sebagai jasa, yaitu produk jasa bank syariah.

Berikut uraian mengenai pihak-pihak yang terkait dengan transaksi L/C, yaitu:

\section{Applicant}

Applicant/pemohon/pembuka L/C adalah pihak yang meminta dan memerintahkan kepada bank untuk membuka L/C untuk keuntungan 
penerima L/C (beneficiary/penjualbarang/eksportir). Dalam perintah kepada bank untuk membuka L/C, pemohon menyatakan bertanggungjawab untuk membayar dokumen sepanjang semua persyaratan yang tertera di dalam $\mathrm{L} / \mathrm{C}$ dipenuhi.

\section{Opening/Issuing Bank}

Opening/issuing Bank yaitu bank yang membuka L/C untuk kepentingan beneficiary (penerima L/C). Di dalam L/C dicantumkan persyaratan yang diminta oleh pembuka, persyaratan mana harus dipenuhi oleh beneficiary (penerima L/C).

3. Advising Bank

Advsing Bank adalah bank yang menerima dan meneruskan L/C kepada beneficiary.

4. Beneficiary

Beneficiary (penerima L/C) adalah penjual/eksportir yang diberi hak untuk menarik sejumlah uang yang tertera dalam L/C dengan memenuhi semua persyaratan yang diminta.

5. Negotiating Bank

Negotiating Bank adalah bank yang mengambil alih dokumen yang dipersyaratkan dalam L/C. Menegosiasi/mengambil alih adalah membayar terlebih dahulu kepada beneficiary atas dokumen yang disyaratkan dalam $\mathrm{L} / \mathrm{C}$ dan kemudian menagih (mereimburs) kepada bank pembuka L/C dengan mengirimkan dokumen yang telah diambil alih.

6. Confirming Bank

Confirming Bank adalah bank yang ikut menjamin terhadap suatu L/C atas permintaan atau otorisasi dari issuing bank (Taswan, 2009: 322).

Sebagaimana diungkapkan oleh Totok Budisantoso, proses terjadinya L/C ini lebih disebabkan karena belum ada unsur kepercayaan antara penjual (eksportir) dan pembeli (importir). Bukan disebabkan karena terkait dengan cidera janji kedua belah pihak, baik penjual maupun pembeli, sebagaimana yang terjadi dalam kontrak bank garansi (Budisantoso, 2006: 128). 
Untuk mengantisipasi tidak saling percaya tersebut, maka penjual mensyaratkan agar pembeli menyerahkan L/C dari bank. Dengan adanya L/ C tersebut, penjual (eksportir) mendapatkan kepastian bahwa setelah mengirimkan barang kepada pembeli (importir), maka dokumen pengiriman beserta dokumen kelengkapannya dapat digunakan untuk menagih pembayaran dari bank penerbit L/C. Dengan demikian perjanjian jual beli antara eksportir dengan importir ini dapat dilaksanakan apabila eksportir percaya bahwa bank penerbit L/C akan menempati janjinya. Janji dalam $\mathrm{L} / \mathrm{C}$ tersebut pada prinsipnya adalah kesediaan bank penerbit L/C untuk membayar sejumlah uang pada saat penjual (eksportir) dapat menunjukkan bukti pengiriman barang serta dokumen pelengkapnya.

Kontrak L/C bukanlah merupakan suatu perjanjian yang dapat berdiri sendiri. L/C lahir dari adanya perjanjian lain, biasanya jual beli barang jarak jauh antara penjual dan pembeli yang belum saling mengenal dengan baik, bahkan tidak pernah bertemu sebelumnya. Perjanjian atau kontrak inilah yang menjadi dasar proses terbentuknya $\mathrm{L} / \mathrm{C}$.

Proses terbentuknya L/C dalam bank syariah sedikit banyak sama dengan proses terbentuknya $\mathrm{L} / \mathrm{C}$ dalam bank konvensional. Hanya saja dalam proses terbentuknya L/C dalam bank syariah, transaksinya harus sesuai dengan prinsip-prinsip syariah itu sendiri.

Dilihat dari proses terjadinya L/C tersebut, dapat dikatakan bahwa L/C juga merupakan pengalihan penanggungan risiko dari penjual dan pembeli yang kemudian diemban oleh pihak bank. Karena itu untuk mengantisipasi risiko yang diemban, bank penerbit mewajibkan kepada importir untuk menyerahkan sejumlah uang sebagai jaminan sebesar 10\% dari nilai $\mathrm{L} / \mathrm{C}$, juga menyerahkan agunan tambahan dari importir atau pemohon L/C (Budisantoso, 2006: 129).

Adapun proses terjadi kontrak dengan menggunakan sarana $\mathrm{L} / \mathrm{C}$ secara rinci dapat dijelaskan sebagai berikut:

1. Eksportir/penjual/beneficiary menandatangani kontrak jual beli (sales contract) dengan pembeli/importir luar negeri;

2. Importir/pembeli/account meminta kepada banknya (bank devisa) untuk membuka suatu L/C untuk dan atas nama eksportir. Dalam hal ini, importir bertindak sebagai opener. Bila importir sudah memenuhi ketentu- 
an yang berlaku untuk impor seperti keharusan adanya surat ijin impor, maka bank melakukan kontrak valuta (KV) dengan importir dan melaksanakan pembukaan L/C atas nama importir. Bank dalam hal ini bertindak sebagai opening/issuing bank. Pembukaan L/C ini dilakukan melalui salah satu koresponden bank di luar negeri. Koresponden bank yang bertindak sebagai perantara kedua ini disebut sebagai advising bank atau notifying bank. Advising bank memberitahukan kepada eksportir mengenai pembukaan L/C tersebut. Eksportir yang menerima L/C disebut beneficiary;

3. Eksportir menghubungi instansi terkait dalam rangka pengiriman/pengapalan barang dan pengurusan perijinan serta dokumen-dokumen yang diperlukan;

4. Eksportir menerima konosemen (Bill of Lading) setelah menyerahkan barang ke carrier;

5. Eksportir menyerahkan dokumen yang disyaratkan dalam L/C (Wesel, Faktur, Konosemen/Airway bill, Certificate of Origin, Certificate of Quality, dan lain-lain) kepada negotiating bank;

6. Bank membayar kepada eksportir setelah melakukan pemeriksaan dokumen yang diserahkan oleh eksportir, bahwa semua persyaratan L/C dipenuhi (tidak ada discrepancy);

7. Bank dalam negeri (sebagai negotiating bank) mengirimkan dokumen ke bank pembuka L/C di luar negeri dan menginstruksikan untuk membayar dan mentransfer pembayaran kepada bank yang ditunjuk;

8. Bank di luar negeri memeriksa dokumen dan menyerahkannya kepada importir untuk mengambil barang di pelabuhan tujuan. Penyerahan dokumen dilakukan setelah importir memenuhi kewajibannya (Adisasmita, 2007: 24).

Tetapi jika importir tidak dapat memenuhi kewajiban sesuai yang kesepakatan sebelumnya, penyelesaiannya Hal ini akan dibahas selanjutnya.

\section{Penyelesaian Kewajiban L/C}

Tipe perjanjian yang dapat difasilitasi dalam L/C terbatas hanya pada perjanjian jual beli. Sedangkan fasilitas yang diberikan adalah berupa penangguhan pembayaran. Dengan fasilitas ini pembeli (importir) tidak harus mem- 
bayar terlebih dahulu sebelum barang dikirim oleh penjual (eksportir). Pembayaran yang dilakukan bank dalam fasilitas $\mathrm{L} / \mathrm{C}$ juga tidak terkait cedera janjinya pihak yang dijamin (importir). Ada cedera janji atau tidak, pihak bank tetap melakukan pembayaran dalam fasilitas L/C (Budisantoso, 2006: 128).

Salah satu fungsi $\mathrm{L} / \mathrm{C}$ adalah sebagai alat pembayaran. L/C sebagai alat pembayaran ini terdiri dari:

1. Irrevocable $L / C$

Irrevocable $\mathrm{L} / \mathrm{C}$ adalah $\mathrm{L} / \mathrm{C}$ yang tidak dapat dibatalkan selama jangka berlaku (validity) yang ditentukan dalam $\mathrm{L} / \mathrm{C}$ tersebut dan opening bank tetap menjamin untuk menerima wesel-wesel yang ditarik atas L/C tersebut. Pembatalan hanya dapat dilakukan jika atas persetujuan semua pihak yang bersangkutan dengan $\mathrm{L} / \mathrm{C}$ tersebut.

2. Revocable L/C

Revocable L/C adalah L/C yang sewaktu-waktu dapat dibatalkan atau diubah secara sepihak oleh opener atau oleh issuing bank tanpa memerlukan persetujuan dari beneficiary.

3. Irrevocable dan confirmed $\mathrm{L} / \mathrm{C}$

L/C ini dianggap paling sempurna dan paling aman dari sudut penerima $\mathrm{L} / \mathrm{C}$ (beneficiary) karena pembayaran atau pelunasan wesel yang ditarik atas L/C ini dijamin sepenuhnya oleh opening bank maupun oleh advising bank, bila segala syarat-syarat dipenuhi, serta tidak mudah dibatalkan karena sifatnya yang irrevocable.

4. Confirmed $\mathrm{L} / \mathrm{C}$

Adalah L/C yang atas permintaan bank pembuka L/C dibubuhi konfirmasi/penegasan dari bank lainnya yang ditunjuk (confirming bank). Penegasan ini menyatakan bahwa bank tersebut ikut bertanggungjawab untuk membayar dokumen yang diserahkan sepanjang seluruh persyaratan L/ $\mathrm{C}$ dipenuhi. Confirming bank akan membubuhkan kalimat "we confirm the credit and hereby undertake that all draft drawn and presented will be honored" dalam L/C yang diadviskan ke beneficiary. 


\section{Clean Letter of Credit}

Dalam L/C ini tidak dicantumkan syarat-syarat lain untuk penarikan suatu wesel. Artinya, tidak diperlukan dokumen-dokumen lainnya, bahkan pengambilan uang dari kredit yang tersedia dapat dilakukan dengan kuitansi biasa.

6. General L/C

Adalah L/C yang dapat dinegosiasi di bank mana saja, biasanya terdapat dalam klausul "this credit can be negotiated at any bank in Indonesia".

7. Restricted $\mathrm{L} / \mathrm{C}$

Restricted $L / C$ adalah $\mathrm{L} / \mathrm{C}$ yang hanya dapat dinegosiasi oleh bank tertentu yang ditunjuk dalam $\mathrm{L} / \mathrm{C}$, biasanya terdapat klausul "this credit negotiable with bank $A$ only" atau "negotiation of this credit is restricted to bank $A$ "

8. Sight Payment L/C

Sight Payment L/C adalah L/C yang mensyaratkan adanya penyerahan sight draft dan dokumen yang disyaratkan.

9. Usance $\mathrm{L} / \mathrm{C}$

Usance $\mathrm{L} / \mathrm{C}$ adalah $\mathrm{L} / \mathrm{C}$ yang mensyaratkan adanya penyerahan wesel berjangka (usance draft) dan dokumen yang disyaratkan dalam L/C. Bank penerbit L/C akan melakukan akseptasi pada wesel berjangka sepanjang semua persyaratan L/C dipenuhi dan akan melakukan pembayaran pada waktu jatuh tempo wesel (on maturity date) berjangka tersebut. Dalam wesel biasanya tertera kalimat "pay at 60 days after $B / L$ date", atau kalimat serupa yang menunjukkan kapan wesel tersebut harus dibayar (Adisasmita, 2007: 37). Usance L/C disebut juga dengan acceptance L/ C. Pada prakteknya akseptasi dilakukan atas wesel berjangka yang ditarik oleh penerima. Akseptasi atas wesel berjangka berarti jaminan pembayaran pada saat jatuh tempo (Ginting, 2002: 40).

10. Negotiation L/C

Negotiation L/C adalah L/C yang pembayarannya dengan cara membeli wesel dan/atau dokumen-dokumen yang diajukan penerima. 


\section{Transferable L/C}

Transferable L/C memberikan hak kepada beneficiary untuk memindahkan atau menguasakan haknya kepada pihak lain (beneficiary kedua).

12. Red clause $L / C$

Red Clause L/C adalah L/C yang mengandung syarat bahwa beneficiary diberi hak untuk menerima sebagian atau seluruh jumlah $\mathrm{L} / \mathrm{C}$ sebelum pengiriman barang (Adisasmita, 2007: 38).

\section{Revolving $\mathrm{L} / \mathrm{C}$}

Revolving L/C adalah L/C yang memberikan hak kepada beneficiary untuk memakai ulang kredit yang tersedia tanpa harus mengadakan perubahan syarat khusus pada L/C tersebut.

\section{Back to Back L/C}

Adalah L/C yang dibuka berdasarkan dan dijamin dengan L/C yang diterima (master L/C). Semua persyaratan yang tertera dalam back to back L/C (jumlah, jenis dan kualitas barang, pelabuhan tujuan serta jenisjenis dokumen, dll) sama dengan persyaratan yang diminta dalam master $\mathrm{L} / \mathrm{C}$, kecuali harga yang tertera dalam wesel dan faktur tidak sama (Adisasmita, 2007: 38).

Fungsi L/C yang yang lain adalah sebagai alat penjamiman. L/C sebagai alat penjaminan ini terdiri dari:

1. Standby $L / C$

Adalah jaminan yang dikeluarkan oleh bank atas permintaan pemohon (applicant) untuk menjamin kepentingan beneficiary bahwa apabila pihak yang dijamin melakukan wanprestasi, maka bank penerbit akan membayarnya atas beban pemohon (Adisasmita, 2007: 38).

\section{Demand Guarantee}

Demand guarantee adalah jaminan yang dibayar berdasarkan pengajuan dokumen-dokumen tertentu kepada bank, untuk menjamin kewajiban penerima dan pemohon. Pembayaran demand guarantee bukan disebabkan adanya wanprestasi atas kontrak dasar, tetapi pembayaran dilakukan atas dasar pengajuan klaim dilengkapi persyaratan formal dari demand guarantee itu sendiri (Ginting, 2002: 54). 
Dari keterangan di atas, dapat difahami bahwa fasilitas yang diberikan oleh bank dalam L/C adalah berupa jasa dan penangguhan pembayaran. Karena itu secara umum dalam bank konvensional terdapat dua kemungkinan dalam hal ini, yaitu:

Kemungkinan pertama, importir membayar lunas tepat waktu kepada bank penerbit. Selanjutnya agunan tambahan akan dikembalikan kepada pembeli dan proses L/C dianggap selesai.

Kemungkinan kedua, importir (pembeli) tidak dapat membayar tepat waktu kepada bank penerbit (jatuh tempo), maka sisa kewajiban (misal 90\%) diubah menjadi kredit biasa yang harus dibayar beserta bunganya. Bunga yang diberlakukan adalah bunga pinjaman umum ditambah dengan penalti/ denda. Jangka waktu dari kredit tersebut didasarkan pada kesepakatan antara pihak bank penerbit dengan pembeli. Selanjutnya pembeli melunasi kredit beserta bunga dan agunan tambahan dikembalikan kepada pembeli. Dengan demikian proses $\mathrm{L} / \mathrm{C}$ selesai.

Ini merupakan gambaran umum proses penyelesaian kewajiban $\mathrm{L} / \mathrm{C}$ yang dilaksanakan oleh bank konvensional, di mana masih terlihat adanya unsur bunga (riba) yang dalam perspektif syariah Islam riba merupakan hal yang diharamkan. Maka konsep L/C syariah harus mengedepankan nilainilai yang sesuai dengan ajaran agama Islam.

Sesuai dengan Fatwa Dewan Syariah Nasional, sebagaimana yang telah dijelaskan sebelumnya, L/C impor yang sesuai dengan syariah dalam pelaksanaannya dapat menggunakan akad-akad:

1. Wakālah bi al-ujrah

2. Wakālah bi al-ujrah dan qarḍ

3. Murābaḥah

4. Salām/istiṣnā' dan murābaḥah

5. Wakālah bi al-ujrah dan muḍāabah

6. Mushārakah

7. Wakālah bi al-ujrah dan hawālah (Fatwa DSN, 2003: 211-222).

Sedangkan untuk L/C ekspor syariah dalam pelaksanaannya dapat menggunakan akad-akad: 
1. Wakālah bi al-ujrah

2. Wakālah bi al-ujrah dan qarḍ

3. Wakālah bi al-ujrah dan muḍārabah

4. Mushārakah

8. Al-Bai' dan Wakālah (Fatwa DSN, 2003: 211-222).

\section{Aplikasi Akad yang Sesuai dengan L/C Syariah}

Letter of Credit (L/C) merupakan salah satu jasa yang ditawarkan oleh bank. Dalam bank konvensional, L/C dimasukkan sebagai non-cash loan dan disebut sebagai fee-based income atau penerimaan yang berasal dari pemberian jasa non-pembiayaan atau investasi (Pandia, 2005: 194). Dalam bank syariah, L/C juga dimasukkan sebagai jasa, yaitu pelayanan jasa bank (Bank Indonesia, 2008: C-1).

Tetapi dalam aplikasinya L/C tidak hanya sebagai pelayanan jasa, L/ $\mathrm{C}$ juga dapat berubah menjadi produk pembiayaan, yaitu kredit biasa. Sebagaimana diungkapkan oleh Adiwarman A. Karim, Letter of Credit (L/ C) dalam bank syariah termasuk produk pembiayaan, yaitu pembiayaan Letter of Credit (L/C) impor atau ekspor syariah. Secara definitif yang dimaksud dengan L/C adalah pembiayaan yang diberikan dalam rangka memfasilitasi transaksi impor atau ekspor nasabah (Karim, 2008: 252).

Perubahan L/C -khususnya L/C impor- dari pelayanan jasa menjadi produk pembiayaan bank, disebabkan karena dua kemungkinan penyelesaian kewajiban dalam L/C, yaitu sebagai berikut:

Kemungkinan pertama, importir membayar lunas tepat waktu kepada bank penerbit, dalam hal ini kemudian agunan tambahan dikembalikan kepada pembeli dan proses $\mathrm{L} / \mathrm{C}$ selesai.

Kemungkinan kedua, importir (pembeli) tidak dapat membayar tepat waktu kepada bank penerbit (jatuh tempo), maka berubah menjadi pembiayaan bank.

Kalau dilihat dari kedua kemungkinan penyelesaian kewajiban dalam L/C tersebut, maka kemungkinan pertama merupakan bentuk L/C yang sesungguhnya, yaitu pelayanan jasa. Di sini bank memberikan jasa kepada importir dan akan memperoleh fee dari jasa yang ditawarkan tersebut. 
Sedangkan kemungkinan kedua merupakan bentuk L/C yang telah berubah menjadi produk pembiayaan. Di sini bank tidak memperoleh fee tapi akan memperoleh keuntungan dari pembiayaan yang ditawarkan.

Kemudian untuk mengurangi risiko masing-masing pihak, mengingat pembukaan L/C juga terjadi karena adanya jual beli antarnegara, maka aplikasi dalam bank syariah tepatnya hanya ada dua akad yang sesuai dengan esensi dari Letter of Credit (Surat Kredit Berdokumen), yaitu akad wakālah bi alujrah dan akad murābaḥah.

Sebelum membahas aplikasi akad wakālah bi al-ujrah dan akad muḍārabah yang digunakan untuk L/C dalam bank syariah, terlebih dahulu akan dijelaskan pengertian dari kedua akad tersebut. Wakālah berarti perlindungan (al-hifz), pencukupan (al-kifāyah), tanggungan (al-dhimmah), atau pendelegasian (al-tafwị $)$, yang diartikan juga dengan memberikan kuasa atau mewakilkan. Secara umum wakālah adalah pelimpahan kekuasaan oleh seseorang sebagai pihak pertama kepada orang lain sebagai pihak kedua dalam hal-hal yang diwakilkan (dalam hal ini pihak kedua). Pihak kedua hanya melaksanakan sesuatu sebatas kuasa atau wewenang yang diberikan oleh pihak pertama. Apabila kuasa itu telah dilaksanakan sesuai yang disyaratkan, maka semua risiko dan tanggung jawab sepenuhnya dibebankan pada pihak pertama atau pemberi kuasa (Basyir, 2000: 94).

Dengan demikian wakālah bi al-ujrah berarti perwakilan dengan upah atau jasa dengan imbalan. Perwakilan merupakan penjualan jasa, yang mana satu pihak mewakilkan (al-muwakkil) pada pihak lain (al-wakīl) dengan memberikan pihak lain tersebut upah sebagai konsekuensi dari jasa yang diberikannya. Wakīl adalah yang mendapatkan kepercayaan dari yang mewakilkan.

Mengenai fee/ujrah/upah ini seperti yang diungkapkan Imam Malik bahwa, upah sangat tidak berkaitan dengan keuntungan. Artinya standar pemberian upah harus disesuaikan dengan usaha yang dilakukan atau sesuai dengan kepayahannya (ujrah bi miqdār mā 'alaja), bukan berpatokan pada harga keuntungan dari suatu komoditi (barang). Sedangkan masalah untung dan rugi merupakan tanggungan pemilik/tuan modal (Malik, tt: 665).

Sedangkan murābaḥah seakar dengan kata al-ribḥ yang berarti keuntungan. Bai' al-murābaḥah secara harfiah berarti jual beli dengan 
mengambil keuntungan. Al-Zuhaili mendefinisikan bai' al-murābahah sebagai jual beli berdasarkan harga pokok dengan tambahan keuntungan (Zuhaili, 1989: 703). Maksudnya adalah jual beli di mana penjual menginformasikan kepada pembeli secara jelas modal yang dikeluarkannya untuk mendapatkan komoditas yang dijual itu dengan tambahan keuntungan (Usmani, 2002: 41). Sedangkan Ibn Qudamah mengatakan murābaḥah adalah jual beli dengan harga pokok ditambah keuntungan tertentu (Ibn Qudamah, 1405 H: 129). Bentuknya adalah si penjual menjual suatu produk dengan memberitahukan kepada si pembeli modal yang dikeluarkannya untuk mendapatkan produk, kemudian menaikkannya menjadi harga jual dengan mengambil keuntungan (Ibn Qudamah, 1988: 94).

Sebagai suatu akad, wakālah dan murābaḥah harus memenuhi unsur-unsur dan syarat-syarat akad pada umumnya di samping syarat-syarat khusus wakālah dan murābaḥah itu sendiri. Unsur-unsur akad secara umum ada tiga, yaitu (1) adanya para pihak (dalam konteks wakālah adalah pihak yang mewakilkan dan wakil, dalam murābaḥah adalah penjual dan pembeli); (2) adanya pernyataan kehendak berupa ijab dan kabul; (3) adanya objek akad yang dapat berupa benda, manfaat benda atau melakukan pekerjaan (dua yang terakhir disebut jasa) (Basyir, 2000: 66). Untuk wakālah objeknya adalah melakukan pekerjaan. Sedangkan untuk akad jual beli murābaḥah objeknya adalah benda, bukan manfaat benda atau melakukan pekerjaan.

Para ulama kontemporer menambahkan unsur akad yang keempat, yaitu tujuan akad (Zuhaili, 1989: 182). Tujuan akad jual beli adalah pemindahan milik atas suatu benda dengan imbalan, tujuan perwakilan adalah pemindahan kuasa atas suatu pekerjaan dengan imbalan atau upah. Tujuan akad menjadi penting sesuai maksud mereka mengadakan akad. Oleh kerenanya disyaratkan tujuan itu tidak bertentangan dengan syariah.

Sedangkan syarat-syarat umum akad, dan berlaku juga terhadap wakālah dan murābaḥah, ada empat macam, yaitu (1) syarat terbentuknya akad, yaitu adanya kecakapan untuk melakukan akad, berbilang pihak, kesesuaian ijab dan kabul, adanya kesatuan majelis akad, objek akad dapat diserahkan, objek akad dapat ditransaksikan, objek dapat ditentukan, tujuan akad sesuai atau tidak bertentangan dengan syariah; (2) syarat sahnya akad, yaitu bebas dari riba, bebas dari syarat rusak (făsid), bebas dari gharar, bebas 
dari paksaan, penyerahan objek tidak menimbulkan bahaya; (3) syarat berlakunya akibat hukum akad, yaitu adanya kewenangan penuh dalam bertindak hukum, adanya kewenangan atas objek; (4) syarat mengikatnya akad, yaitu bebas dari opsi pembatalan (Basyir, 2000: 77). Syarat terakhir ini dibutuhkan agar akad tidak dapat dibatalkan secara sepihak oleh salah satu pihak, baik pihak yang mewakilkan (al-muwakkil) dan yang diwakilkan (alwakìl) dalam akad wakālah, juga penjual dan pembeli dalam akad murābaḥah.

Jual beli murābaḥah harus memenuhi syarat-syarat khusus disamping syarat-syarat yang berlaku umum terhadap seluruh akad. Syarat-syarat khusus tersebut adalah: (1) harga pokok (modal) barang diketahui; (2) disepakati keuntungan yang diberikan; (3) imbalan atas barang, bila tidak berupa uang, harus merupakan benda bercontoh (mithly) dan tidak boleh berupa benda tidak bercontoh atau qimy (Anwar, 2006: 87).

Dalam bank syariah, akad wakālah bi al-ujrah dapat digunakan sebagai perjanjian pembukaan $\mathrm{L} / \mathrm{C}$ dan penyelesaian kewajiban dari kemungkinan pertama di atas. Nasabah dalam hal ini menunjuk bank sebagai wakil dalam hal pengurusan dokumen-dokumen transaksi impor hingga urusan pembayaran kepada beneficiary (penerima L/C). Secara sederhana prinsip ini dapat terlaksana apabila nasabah memiliki dana cukup dan membayar lunas tepat waktu sehingga proses L/C selesai dan bank memperoleh fee atau ujrah (upah) yang sudah disepakati bersama sejak awal perjanjian, dan dinyatakan dalam bentuk nominal bukan dalam bentuk persentase. Artinya ada kejelasan upah atau keuntungan yang diperoleh bank melalui akad wakālah bi al-ujrah. (Fatwa DSN, 2003: 218). Sedang fee yang diperoleh bank syariah, merujuk dari pendapat Imam Malik di atas, fee tidak berkaitan dengan keuntungan komoditi yang diimpor. Fee yang diperoleh bank harus disesuaikan dengan kepayahan dari pekerjaan yang akan dilakukan.

Dengan menggunakan akad wakālah bi al-ujrah, bank harus memperhatikan unsur-unsur dan syarat-syarat umum akad wakālah yang telah disebutkan di atas. Dalam aplikasinya bank syariah juga diperbolehkan meminta uang muka ('urbūn) dan agunan kepada nasabah sebagai bukti keseriusan dari nasabah. 'Urbūn tersebut harus diperhitungkan berdasarkan harga barang. Saat proses pembayaran telah lunas, jaminan (agunan) harus dikembalikan kepada nasabah, maka proses L/C selesai. 
Sedangkan akad murābaḥah dapat digunakan oleh bank syariah sebagai perjanjian pembukaan $\mathrm{L} / \mathrm{C}$ dan penyelesaian kewajiban dari kemungkinan kedua di atas. Akad murābaḥah dapat digunakan untuk nasabah yang tidak mempunyai cukup dana. Dalam akad ini bank syariah bertindak selaku pembeli yang mewakilkan kepada importir untuk melakukan transaksi dengan eksportir. Dalam hal ini pengurusan dokumen dan pembayaran dilakukan oleh bank saat dokumen diterima dan/atau tangguh sampai dengan jatuh tempo. Selanjutnya bank menjual barang secara murābaḥah kepada importir, dan biaya-biaya yang dikeluarkan oleh bank akan diperhitungkan sebagai harga perolehan barang (Fatwa DSN, 2003: 218).

Dalam prakteknya, bank harus memperhatikan unsur-unsur, syaratsyarat umum dan syarat-syarat khusus akad murābaḥah yang telah disebutkan di atas. Jaminan juga diperlukan dalam akad murābaḥah untuk memperkecil risiko-risiko yang merugikan bank dan untuk melihat kemampuan nasabah dalam menanggung pembayaran kembali atas utang yang diterima dari bank. Sedangkan Keuntungan L/C dalam akad muräbaḥah harus disepakati bersama, yaitu harga barang ditambah dengan keuntungan. Besar keuntungan dapat dinyatakan dalam nominal rupiah tertentu atau dalam bentuk persentase dari harga pembelian barang (Karim, 2008: 113). Jika pembayaran telah lunas dalam jangka waktu tertentu, sebagaimana yang telah disepakati sebelumnya (saat terjadinya akad), jaminan harus dikembalikan kepada nasabah, dan selanjutnya proses L/C dianggap selesai.

\section{Penutup}

Letter of Credit (L/C) dalam bahasa Indonesia sering disebut sebagai Surat Kredit Berdokumen. L/C dalam bank syariah termasuk jasa dan produk pembiayaan, yaitu pembiayaan Letter of Credit (L/C) impor atau ekspor syariah.

L/C impor syariah adalah surat pernyataan akan membayar kepada eksportir (beneficiary) yang diterbitkan oleh bank (issuing bank) atas permintaan importir dengan pemenuhan persyaratan tertentu sesuai dengan prinsip syariah. Sedangkan L/C ekspor syariah adalah surat pernyataan akan membayar kepada eksportir yang diterbitkan oleh bank untuk memfasilitasi 
perdagangan ekspor dengan pemenuhan persyaratan tertentu sesuai dengan prinsip syariah.

Sebagai pelayanan jasa dan produk pembiayaan transaksi jual beli perdagangan internasional, dan dilihat dari proses terjadinya $\mathrm{L} / \mathrm{C}$ sendiri, maka akad wakālah bi al-ujrah dan murābaḥah lebih sesuai dengan esensi dari Letter of Credit (L/C) syariah. Bank syariah dapat menerapkan L/C pada dua sisi, satu sisi sebagai pelayanan jasa, disisi lain sebagai pembiayaan jual beli. Dengan kedua akad ini bank syariah dapat meminimalisir risiko-risiko yang akan merugikan bank syariah itu sendiri.

\section{Daftar Pustaka}

Adisasmita, Tjarsim. 2007. Menangani Transaksi Ekspor Berdasarkan Letter of Credit. Jakarta: Puja Almasar Lestari Consultant (Palcons).

Anwar, Syamsul. 2006. Studi Hukum Islam Kontempoer. Yogyakarta: Cakrawala.

Bank Indonesia. 2008. Kodifikasi Produk Perbankan Syariah. Direktorat Perbankan Syariah Bank Indonesia.

Basyir, Ahmad Azhar. 2000. Asas-Asas Hukum Muamalah; Hukum Perdata Islam. Yogyakarta: UII Press.

Budisantoso, Totok. 2006. Bank dan Lembaga Keuangan Lain. Jakarta: Selemba Empat.

Ginting, Ramlan. 2002. Letter of Credit; Tinjauan Aspek Hukum dan Bisnis. Jakarta: Salemba Empat.

Himpunan Fatwa Dewan Syariah Nasional. 2003. Diterbitkan Atas Kerjasama Dewan Syariah Nasional Majelis Ulama Indonesia dengan Bank Indonesia.

Ibn Qudāmah. 1405 H. al-Mughni. Beirut: Dār al-Fikr.

Ibn Qudāmah. 1988. Al-Kāfi fî Fiqh Ibn Hanbal. Beirut: al-Maktab al-Islāmi.

Karim, Adiwarman A. 2008. Bank Islam; Analisis Fiqh dan Keuangan. Jakarta: RajaGrafindo Persada.

Kasmir. 2002. Bank dan Lembaga Keuangan Lainnya. Jakarta: RajaGrafindo Persada.

Malik Ibn Anas, Imām al-A-immah wa 'Ālim al-Madinah. t.t. al-Muwatța'. II. Bairut Lebanon: Dār al-Ilmiyyah.

Pandia, Frianto, dkk. 2005. Lembaga Keuangan. Jakarta: Rineka Cipta. 
Taswan. 2008. Akuntansi Perbankan; Transaksi dalam Valuta Rupiah. Yogyakarta: UPP STIM YKPN.

Usmani. 2002. An Introduction to Islamic Finance. The Haque: Kluwer Law International.

Widjaja, Gunawan \& Ahmad Yani. 2001. Transaksi Bisnis Internasional; Ekspor-Impor \& Imbal Beli. Jakarta: Raja Grafindo Persada.

Zuhaili, Wahbah al-. 1989. IV. al-Fiqh al-Islami wa Adillatuh. Damaskus: Dar al-Fikr. 